\title{
MEMORY in RETURNS AND Volatilities of Futures' Contracts
}

\author{
NUNO CRATO \\ BONNIE K. RAY*
}

\begin{abstract}
Various authors claim to have found evidence of stochastic long-memory behavior in futures' contract returns using the Hurst statistic. This paper reexamines futures' returns for evidence of persistent behavior using a biased-corrected version of the Hurst statistic, a nonparametric spectral test, and a spectral-regression estimate of the longmemory parameter. Results based on these new methods provide no evidence for persistent behavior in futures' returns. However, they provide overwhelming evidence of long-memory behavior for the volatility of futures' returns. This finding adds to the emerging literature on persistent volatility in financial markets and suggests the use of new methods of forecasting volatility, assessing risk, and optimizing portfolios in futures' markets. (C) 2000 John Wiley \& Sons, Inc. Jrl Fut Mark 20:525-543, 2000
\end{abstract}

\footnotetext{
The work of Bonnie K. Ray was funded partially under NSF grant DMS-9623884. The authors gratefully acknowledge the computational help of students Chernok Chernilos, Steven Davidson, Jean-Charles Gresset, and Roxanne Sosa during the course of a statistics project concerning longmemory time series.

${ }^{*}$ Correspondence author, Bonnie K. Ray, Department of Mathematical Sciences, New Jersey Institute of Technology, Newark, NJ 07102.

Received January, 1999; Accepted September, 1999.
}

- Nuno Crato is an Assistant Professor in the Department of Mathematics at the Instituto Superior de Economia e Gestao, UTL in Lisbon, Portugal.

- Bonnie K. Ray is an Associate Professor in the Department of Mathematical Sciences at the New Jersey Institute of Technology in Newark, New Jersey.

The Journal of Futures Markets, Vol. 20, No. 6, 525-543 (2000)

(c) 2000 by John Wiley \& Sons, Inc. 


\section{INTRODUCTION}

An important issue in the study of financial markets is the evaluation of the stochastic memory of market returns. If returns have a stochastic memory, it is possible to obtain increased profits on the basis of pricechange predictions. Such predictability would contradict the efficient market hypothesis (see e.g., Ball, 1989), which states that increased profits cannot be made consistently by trading on the basis of information given by past prices.

Over twenty years ago, Mandelbrot's work $(1965,1972)$ on the use of the Rescaled Adjusted Range Statistic (R/S) stimulated the use of this statistic for analyzing the fractal behavior and stochastic memory of financial time series. Using R/S analysis, Greene and Fielitz (1977), Booth, Kaen, and Koveos (1982a, 1982b), and other researchers arrived at the surprising conclusion that some financial time series have long-memory behavior. In particular, Helms, Kaen, and Rosenman (1984) analyzed price changes in futures' contracts and claimed that the returns of the series displayed long-memory characteristics. The claim of long memory on commodity futures' price changes goes further than the simple claim of some statistical dependence that could improve the predictability of the prices: It states that correlations between price changes die out very slowly, in a sense made precise below, so that the actual movements in the market are influenced stochastically by the recent to the most remote past.

More recent work on R/S analysis (Lo, 1991) has demonstrated that this statistic is biased when short-range correlation is present in a series, calling into question earlier claims of persistence in futures' returns. Using new statistical tools, many authors (Cheung \& Lai, 1993; Crato, 1994; Fung \& Lo, 1993) have found that financial returns on the major markets have no significant memory. However, the original claims of Helms et al. (1984) concerning the memory of futures' returns never were reevaluated in light of the new statistical tools. Doukas (1990) found unit roots on most of the returns series, although the existence of a unit root does not preclude long-memory behavior. For a long time, the issue was not investigated further. Recently, Barkoulas, Labys, and Onochie (1997) used the classical R/S analysis to reevaluate the memory of futures' returns. Studying a large new data set, they claimed to have found persistent long memory in a significant group of futures' contracts.

This paper rexamines the memory of futures' returns using three different methods: (i) a modified version of the R/S statistic developed by Lo (1991), (ii) the nonparametric spectral test of Lobato and Robinson (1998), and (iii) a test based on the estimator of the long-memory param- 
eter due to Geweke and Porter-Hudak (1983), henceforth GPH. Our results indicate no long-memory behavior in futures' returns. However, a similar analysis applied to the volatility of the returns finds overwhelming evidence of persistence in volatility. This finding is consistent with recent work by Ding, Granger, and Engle (1993), de Lima and Crato (1993), Bollerslev and Mikkelsen (1996), Baillie, Bollerslev, and Mikkelsen (1996), and Breidt, Crato, and de Lima (1998), among others, which finds compelling evidence that the volatility of financial markets displays a long-memory structure. As Engle (1982), Bollerslev (1986), and others have shown, the volatility of financial returns may display a strong autocorrelation structure while the level of the returns display no memory and a random-walk-type behavior. This finding in futures' series behavior adds to the emerging literature on persistent volatility in financial markets and suggests the use of new methods of forecasting volatility, assessing risk, and optimizing portfolios in futures' markets.

The plan of the rest of the paper is as follows. First we will define the concepts of short and long memory of a random process and describe tests for long-memory behavior. Then we will describe the data sets and present the new empirical findings for both futures' returns and volatilities. We then will introduce the long-memory stochastic volatility (LMSV) model and illustrate its use for a particular series of futures' contract returns.

\section{THE MEMORY OF A TIME SERIES}

The expected relationship between the value of a process at time $t$ and its value at time $t-k$ is a measure of the correlation present in the series. A stationary time series has correlation that depends only on the time lag $k$ between the two observations, and decays to zero as $k$ increases, reflecting the fact that the influence of the past values decreases with the lags under consideration. The speed of this decay is a measure of the stochastic "memory" of the random process.

A process in which all observations are uncorrelated is called a white noise, and the random process is said to have no memory. One commonly assumed implication of the Efficient Market Hypothesis is that futures' returns follow such a process. Processes with short memory are those that have autocorrelations decaying to zero at a geometric rate. AutoRegressive Moving Average (ARMA) models are examples of such processes. In contrast, a long-memory process has autocorrelations that decay much more slowly, asymptotically following a hyperbolic decay. More precisely, a stationary process $\left\{X_{t}\right\}$ is said to have long memory if, for some 
$C>0$ and $d<0.5$, its autocovariance function, $\gamma(k)=E\left[\left(X_{t}-\mu\right)\left(X_{t+k}\right.\right.$

$-\mu)$ ], has asymptotic behavior

$$
|\gamma(k)| \sim C|k|^{2 d-1} \text { as } k \rightarrow \infty,
$$

for $d \neq 0$. If $d>0$, so that $\Sigma|\gamma(k)|=\infty$, the process is said to be persistent.

Equivalently, a long-memory process can be characterized in the frequency domain by the following form of its spectral-density function, $f$ $(\lambda)$, at frequency $\lambda$ :

$$
f(\lambda)=\left|1-e^{-i \lambda}\right|^{-2 d} f_{U}(\lambda),
$$

where $d \neq 0$ and $f_{U}$ is finite and bounded above from zero at the origin.

There are many tests and statistics to detect the existence of long memory in a time series. One of the first tools to be developed was the $\mathrm{R} / \mathrm{S}$ method.

\section{R/S Analysis}

Let $X_{1}, X_{2}, \ldots X_{n}$ represent the observations in $n$ successive periods, and let $\bar{X}$ represent the empirical average. The adjusted range, $R$, is defined as

$$
R(d):=\max _{0 \leq k \leq n}\left\{\sum_{i=1}^{k} X_{i}-k \bar{X}\right\}-\min _{0 \leq \ell \leq n}\left\{\sum_{i=1}^{\ell} X_{i}-\ell \bar{X}\right\} .
$$

A normalization factor $S$ is an estimate of the standard deviation of the process. The estimator can be written in the general form

$$
S(n, q):=\sqrt{\sum_{j=-q}^{q} w_{q}(j) \hat{\gamma}(j)},
$$

where $\hat{\gamma}(j)$ is an estimate of the process autocovariance at lag $j$, and $w_{q}(j)$ are weights. The $\mathrm{R} / \mathrm{S}$ statistic then is defined as

$$
Q(n, q):=\frac{R(n)}{S(n, q)}
$$

In the classical R/S analysis applied by Helms et al. (1984) and by Barkoulas et al. (1997), $q=0, w_{0}(0)=1$, and so $S(n, q)$ is simply the usual sample standard deviation estimate. The distribution of this classical $\mathrm{R} / \mathrm{S}$ statistic $(q=0)$ is not known, and short-memory components can affect the $R / S$ values in a non-negligible way. A modified $R / S$ statistic, 
having $q \neq 0$, was constructed by Lo (1991) to handle these problems. Lo used the weights proposed by Newey and West (1987), $w_{q}(j):=1-$ $j /(q+1)$ with $q<n$. For choosing the truncation parameter $q$, Lo followed Andrews' (1987) suggestion of setting $q$ as the greatest integer less than or equal to the data dependent quantity

$$
\left(\frac{3 n}{2}\right)^{1 / 3}\left(\frac{2 \hat{\rho}(1)}{1-\hat{\rho}^{2}(1)}\right)^{2 / 3}
$$

where $\hat{\rho}(1)$ is an estimate of the first-order autocorrelation of the process. The modified estimator is invariant over a general class of short-memory processes, but is sensitive to the presence of long memory. If only short memory is present, then $Q(n, q) / \sqrt{n}$ converges weakly to the range of the Brownian bridge on the unit interval. The distribution function for this range is given by Kennedy (1976) and Siddiqui (1976). It can be expressed as $F(v)=\sum_{k=-\infty}^{\infty}\left(1-4 v^{2} k^{2}\right) e^{-2 v^{2} k^{2}}$, from which critical values can be computed to test the null hypothesis of no long-range dependence.

For ARMA and other short-memory processes, the values of $Q(n, q)$ converge to $n^{J}$ with $J=1 / 2$. The parameter $J$ is called the Hurst exponent and is related to the long-memory parameter $d$ discussed above by $J=d$ $+1 / 2$. Mandelbrot and coworkers proved in a series of papers (see, for instance, Mandelbrot \& Taqqu, 1979) that when $J>1 / 2$, a process has long memory. Various methods can be used in $\mathrm{R} / \mathrm{S}$ analysis to estimate the $J$. A natural estimate for a series of length $n$ is simply

$$
\hat{J}=\frac{\log Q(n, q)}{\log n} .
$$

No distributional results are available currently for this estimate of $J$.

\section{GPH Spectral Regression}

The second method we have used for determining the existence of longrange dependence in a time series is based on the spectral form of a longrange dependent process, as given in (2). Geweke and Porter-Hudak (1983) suggested regressing the log of the estimated spectrum of the series on the log of the frequency values themselves. They also suggested that the regression be performed using a set of Fourier frequencies close to zero, where the slope of the log spectrum relative to the frequency is dependent directly on the long-memory parameter $d$. They argued that their regression estimator could capture the long-memory characteristic 
of the process without being "contaminated" in the estimation by shortmemory correlation in the time series evident at higher frequencies.

Use of this method requires choice of a truncation parameter $m$ to determine the number of Fourier frequencies to be considered. Based on simulations, Geweke and Porter-Hudak suggested the use of $m=\left[n^{u}\right]$ with $u=.5$, where $n$ is the number of observations and $[\cdot]$ is the greatest integer function. Robinson (1995) argued that a consistent estimator for $d$ could be obtained if an additional low-order truncation $l>1$ was introduced, thus using the Fourier frequencies $j=l, 2, \ldots, m$. More recent results by Hurvich, Deo, and Brodsky (1998) found that this lower truncation is not necessary. They concluded that setting $l=1$ i.e., no lower truncation, and $\left[n^{\cdot 6}\right]$ for the upper truncation is a more optimal choice. We have tried a range of possible values for both upper and lower truncations in order to have more robust results.

The distribution of the estimated $d$ parameter can be shown to be Gaussian under certain conditions, and thus a test for $H_{o}: d=0$ (no long memory) can be performed as a usual $t$-test, using the standard deviation given by the regression.

\section{Nonparametric LM Spectral Test}

A third tool we have used is the nonparametric spectral test constructed by Lobato and Robinson (1998). This is a test for stationary short memory, i.e., integration of order zero of the time series, $X_{t} \sim I(0)$, against fractional alternatives, $X_{t} \sim I(d)$ with $d \neq 0$.

This test uses the periodogram ordinates $I\left(w_{j}\right)$ at the Fourier frequencies $w_{j}=2 \pi j / n$, where $j=1,2, \ldots, m<n / 2$ and $n$ is the length of the series. The truncation parameter $m$ is chosen in order to use a sensible number of low-order frequencies whose values essentially are determined by the long-memory component of the process. Without the previous knowledge of the memory parameter, there is no clear rule for determining the value of the truncation $m$. Thus, we have used a set of values consistent with the simulation results available in the original paper.

The testing statistic is based on the Lagrange Multiplier (LM) principle and takes the form

$$
t=-\sqrt{n} \sum_{j=1}^{m} v_{j} I\left(w_{j}\right) / \sum_{j=1}^{m} I\left(w_{j}\right),
$$

where $v_{j}=\ln j=m^{-1}\left(\sum_{j=1}^{m} \ln (j)\right)$. This statistic is asymptotically standard normal under the short-memory assumption. Rejection of the null 
hypothesis in the direction of persistent long memory $(d>0)$ occurs at the upper tail of the distribution.

In the next section, these three methods are applied to two sets of futures' returns data.

\section{TESTING FOR LONG MEMORY IN FUTURES' RETURNS}

The first data set to be considered is the set of six daily-returns series previously analyzed by Helms et al. (1984). They correspond to soybean oil (BO), soybean (SO), and soybean meal (SM) contracts for March 1976 (M76) and January 1977 (J77), comprising approximately 230 observations each. The second data set to be considered is an extension of the data set used by Barkoulas et al. (1997). It consists of 17 commodities, five major currencies, and one U.S. stock index. The price data are daily settlement prices of the nearest-to-expiration contract over approximately the last 20 years. At the beginning of the month in which the near contract matures, the price of the successive contract is used as the next price value. The earliest start date is January 3, 1977, and the latest end date is November 28, 1997. The appendix lists the data sets, along with the exchange in which the trade takes place, and the start and end dates of the series. The data were obtained from Market Research Inc., associated with the Chicago Board of Trade. For each contract, the time series of returns is analyzed. For a given series of futures' prices, $p_{t}$, the returns, $r_{t}^{*}$, are computed as the first differences of the $\log$ prices: $r_{t}^{*}=\log p_{t}-$ $\log p_{t-1}$.

Table I gives the results for the three-methods analysis of the Helms data. Table II presents corresponding results for the extended data set. The first three columns of the tables show the estimated Hurst coefficients, $J$, computed from the R/S statistic, as in (5). In the first column, the truncation parameter $q$ for the computations is zero, i.e., the estimates are based on the classical R/S statistic. The second and third columns show results for $q \neq 0$, with estimates based on the corrected statistic of Lo (1991). The first corrected estimates in the second column use a reasonably high truncation parameter, yielding conservative tests for long memory. The second corrected estimates in the third column use the value $q^{*}$ chosen by Andrews' data-dependent formula presented in (4). An extensive set of truncation values $q$ also was tried; these results are available upon request. The estimates essentially are similar for reasonable non-zero values of $q$. 
TABLE I

Memory Estimates for the Helms Data Returns

\begin{tabular}{|c|c|c|c|c|c|c|c|c|c|}
\hline \multirow[b]{2}{*}{ Series } & \multicolumn{3}{|c|}{$\begin{array}{c}\text { Hurst } \\
\text { Estimates } \hat{J}\end{array}$} & \multicolumn{3}{|c|}{$\begin{array}{c}\text { GPH } \\
\text { Estimates } \hat{d}\end{array}$} & \multicolumn{3}{|c|}{$\begin{array}{c}\text { Nonparametric } \\
\text { LM Test }\end{array}$} \\
\hline & $q=0$ & $q=5$ & $q=q^{*}$ & $\begin{array}{c}m=\left[n^{0.50}\right] \\
l=1\end{array}$ & $\begin{array}{c}m=\left[n^{0.60}\right] \\
l=1\end{array}$ & $\begin{array}{c}m=\left[n^{0.60}\right] \\
l=2\end{array}$ & $m=\left[n^{50}\right]$ & $m=\left[n^{.55}\right]$ & $m=\left[n^{.60}\right]$ \\
\hline BO M76 & $\begin{array}{c}0.536 \\
{[0.500]}\end{array}$ & $\begin{array}{c}0.540 \\
{[0.460]}\end{array}$ & $\begin{array}{c}0.534 \\
{[0.525]}\end{array}$ & $\begin{array}{c}0.211 \\
(0.182)\end{array}$ & $\begin{array}{c}0.189 \\
(0.190)\end{array}$ & $\begin{array}{r}-0.223 \\
(0.110)\end{array}$ & $\begin{array}{c}0.029 \\
{[0.488]}\end{array}$ & $\begin{array}{c}-0.199 \\
{[0.579]}\end{array}$ & $\begin{array}{c}-0.431 \\
{[0.667]}\end{array}$ \\
\hline BO J77 & $\begin{array}{c}0.506 \\
{[0.781]}\end{array}$ & $\begin{array}{c}0.513 \\
{[0.721]}\end{array}$ & $\begin{array}{c}0.515 \\
{[0.706]}\end{array}$ & $\begin{array}{c}0.136 \\
(0.161)\end{array}$ & $\begin{array}{c}0.176 \\
(0.125)\end{array}$ & $\begin{array}{c}0.164 \\
(0.253)\end{array}$ & $\begin{array}{c}-0.310 \\
{[0.622]}\end{array}$ & $\begin{array}{r}-0.135 \\
{[0.554]}\end{array}$ & $\begin{array}{c}-0.109 \\
{[0.543]}\end{array}$ \\
\hline SO M76 & $\begin{array}{c}0.525 \\
{[0.605]}\end{array}$ & $\begin{array}{c}0.529 \\
{[0.571]}\end{array}$ & $\begin{array}{c}0.528 \\
{[0.582]}\end{array}$ & $\begin{array}{c}0.021 \\
(0.131)\end{array}$ & $\begin{array}{r}-0.076 \\
(0.083)\end{array}$ & $\begin{array}{c}0.195 \\
(0.272)\end{array}$ & $\begin{array}{c}0.779 \\
{[0.218]}\end{array}$ & $\begin{array}{c}0.193 \\
{[0.424]}\end{array}$ & $\begin{array}{c}0.288 \\
{[0.387]}\end{array}$ \\
\hline SO J77 & $\begin{array}{c}0.541 \\
{[0.440]}\end{array}$ & $\begin{array}{c}0.536 \\
{[0.492]}\end{array}$ & $\begin{array}{c}0.541 \\
{[0.440]}\end{array}$ & $\begin{array}{c}0.265 \\
(0.296)\end{array}$ & $\begin{array}{c}0.057 \\
(0.172)\end{array}$ & $\begin{array}{c}0.230 \\
(0.178)\end{array}$ & $\begin{array}{c}-0.001 \\
{[0.506]}\end{array}$ & $\begin{array}{c}0.313 \\
{[0.377]}\end{array}$ & $\begin{array}{c}0.177 \\
{[0.430]}\end{array}$ \\
\hline SM M76 & $\begin{array}{c}0.532 \\
{[0.549]}\end{array}$ & $\begin{array}{c}0.557 \\
{[0.319]}\end{array}$ & $\begin{array}{c}0.540 \\
{[0.480]}\end{array}$ & $\begin{array}{c}0.118 \\
(0.228)\end{array}$ & $\begin{array}{c}-0.032 \\
(0.152)\end{array}$ & $\begin{array}{c}-0.239 \\
(0.221)\end{array}$ & $\begin{array}{c}-0.255 \\
{[0.601]}\end{array}$ & $\begin{array}{c}-0.081 \\
{[0.532]}\end{array}$ & $\begin{array}{c}-0.643 \\
{[0.740]}\end{array}$ \\
\hline SM J77 & $\begin{array}{c}0.546 \\
{[0.407]}\end{array}$ & $\begin{array}{c}0.555 \\
{[0.328]}\end{array}$ & $\begin{array}{c}0.553 \\
{[0.347]}\end{array}$ & $\begin{array}{c}0.015 \\
(0.113)\end{array}$ & $\begin{array}{c}0.183 \\
(0.135)\end{array}$ & $\begin{array}{c}0.264 \\
(0.198)\end{array}$ & $\begin{array}{c}-0.001 \\
{[0.506]}\end{array}$ & $\begin{array}{c}0.312 \\
{[0.377]}\end{array}$ & $\begin{array}{c}0.177 \\
{[0.430]}\end{array}$ \\
\hline
\end{tabular}

Values in brackets below the estimates for $J$ (Hurst estimates) and below the statistics $t$ (LM test) are the $p$ values for the one-sided test for persistent long memory. Values in parentheses below the estimates for $d$ (GPH estimates) are the standard errors for the estimates.

The values given within square brackets below the estimated $J$ are $p$ values corresponding to the probability of obtaining a value at least as high for the Hurst exponent as the one obtained under the null hypothesis of short memory. For the corrected R/S of Lo $(q \neq 0)$, the $p$ values of the estimates for $J$ are computed as the tail probabilities of the corresponding values of the $\mathrm{R} / \mathrm{S}$ statistic under the short-memory null. The $p$ values shown for the classical R/S statistic $(q=0)$ are appropriate only if the series are uncorrelated.

The next three columns of the tables show the GPH estimates of $d$ for different truncation values $l$ and $m$. The values given within parentheses below the estimated $d$ are the estimated standard deviations of the estimates for $d$, computed as the standard error given by the regression.

The last three columns show the results of the nonparametric LM test. The table shows the values of the statistic $t$ from eq. (6) for different truncations. The values given within brackets below the statistics are the $p$ values of the one-sided tests for persistent long memory $(d>0)$.

A simple inspection of Table I reveals the contrast between the results based on classical R/S estimates $(q=0)$ and those based on the modified R/S statistics. With the possible exception of the soybean oil 76 contract (BO M76), all the classical R/S estimates clearly indicate values 
TABLE II

Memory Estimates for the Extended Data Returns

\begin{tabular}{|c|c|c|c|c|c|c|c|c|c|}
\hline \multirow[b]{2}{*}{ Series } & \multicolumn{3}{|c|}{$\begin{array}{c}\text { Hurst } \\
\text { Estimates } \hat{J}\end{array}$} & \multicolumn{3}{|c|}{$\begin{array}{c}\text { GPH } \\
\text { Estimates } \hat{d}\end{array}$} & \multicolumn{3}{|c|}{$\begin{array}{c}\text { Nonparametric } \\
\text { LM Test }\end{array}$} \\
\hline & $q=0$ & $q=5$ & $q=q^{*}$ & $\begin{array}{c}m=\left[n^{0.50}\right] \\
l=1\end{array}$ & $\begin{array}{c}m=\left[n^{0.60}\right] \\
\quad l=1\end{array}$ & $\begin{array}{c}m=\left[n^{0.60}\right] \\
l=3\end{array}$ & $m=\left[n^{.50}\right]$ & $m=\left[n^{.55}\right]$ & $m=\left[n^{6}\right.$ \\
\hline $\mathrm{BO}$ & $\begin{array}{c}0.480 \\
{[0.961]}\end{array}$ & $\begin{array}{c}0.478 \\
{[0.969]}\end{array}$ & $\begin{array}{c}0.477 \\
{[0.970]}\end{array}$ & $\begin{array}{c}-0.165 \\
(0.069)\end{array}$ & $\begin{array}{c}0.010 \\
(0.053)\end{array}$ & & $\begin{array}{c}-0.804 \\
{[0.789]}\end{array}$ & $\begin{array}{c}0.204 \\
{[0.419]}\end{array}$ & $\begin{array}{c}0.384 \\
{[0.351]}\end{array}$ \\
\hline $\mathrm{BP}$ & $\begin{array}{c}0.562 \\
{[0.067]}\end{array}$ & $\begin{array}{c}0.562 \\
{[0.066]}\end{array}$ & $\begin{array}{c}0.561 \\
{[0.072]}\end{array}$ & $\begin{array}{c}0.033 \\
(0.075)\end{array}$ & $\begin{array}{c}0.059 \\
(0.053)\end{array}$ & $\begin{array}{c}0.035 \\
(0.059)\end{array}$ & $\begin{array}{c}0.757 \\
{[0.225]}\end{array}$ & $\begin{array}{c}1.452 \\
{[0.073]}\end{array}$ & $\begin{array}{c}0.982 \\
{[0.177]}\end{array}$ \\
\hline $\mathrm{JC}$ & $\begin{array}{c}0.533 \\
{[0.351]}\end{array}$ & $\begin{array}{c}0.506 \\
{[0.756]}\end{array}$ & $\begin{array}{c}0.506 \\
{[0.756]}\end{array}$ & $\begin{array}{c}0.043 \\
(0.085)\end{array}$ & $\begin{array}{c}-0.003 \\
(0.054)\end{array}$ & $\begin{array}{c}0.012 \\
(0.061)\end{array}$ & $\begin{array}{c}-0.297 \\
{[0.617]}\end{array}$ & $\begin{array}{c}-0.732 \\
{[0.768]}\end{array}$ & $\begin{array}{r}-0.768 \\
{[0.779]}\end{array}$ \\
\hline$C D$ & $\begin{array}{c}0.569 \\
{[0.037]}\end{array}$ & $\begin{array}{c}0.568 \\
{[0.039]}\end{array}$ & $\begin{array}{c}0.568 \\
{[0.038]}\end{array}$ & $\begin{array}{c}-0.022 \\
(0.085)\end{array}$ & $\begin{array}{c}-0.038 \\
(0.051)\end{array}$ & $\begin{array}{c}-0.087 \\
(0.056)\end{array}$ & $\begin{array}{c}-0.152 \\
{[0.560]}\end{array}$ & $\begin{array}{c}0.010 \\
{[0.496]}\end{array}$ & $\begin{array}{c}-0.292 \\
{[0.615]}\end{array}$ \\
\hline CT & $\begin{array}{c}0.559 \\
{[0.080]}\end{array}$ & $\begin{array}{c}0.531 \\
{[0.384]}\end{array}$ & $\begin{array}{c}0.531 \\
{[0.388]}\end{array}$ & $\begin{array}{c}0.030 \\
(0.077)\end{array}$ & $\begin{array}{r}-0.020 \\
(0.046)\end{array}$ & $\begin{array}{r}-0.0 \\
(0.0\end{array}$ & & $\begin{array}{c}-0.201 \\
{[0.580]}\end{array}$ & $\begin{array}{c}-0.198 \\
{[0.578]}\end{array}$ \\
\hline DM & & $\begin{array}{c}0.549 \\
{[0.160]}\end{array}$ & $\begin{array}{c}0.552 \\
{[0.132]}\end{array}$ & & & & & & \\
\hline FC & & & & & $\begin{array}{c}-0.026 \\
(0.057)\end{array}$ & & & & \\
\hline GC & & $\begin{array}{c}0.576 \\
{[0.017]}\end{array}$ & $\begin{array}{c}0.577 \\
{[0.016]}\end{array}$ & & & & & & \\
\hline$H G$ & $\begin{array}{c}0.504 \\
{[0.778]}\end{array}$ & $\begin{array}{c}0.504 \\
{[0.772]}\end{array}$ & $\begin{array}{c}0.503 \\
{[0.786]}\end{array}$ & $\begin{array}{r}-0.0 \\
(0.0\end{array}$ & $\begin{array}{r}0.0 \\
(0.0\end{array}$ & & $\begin{array}{r}-0.155 \\
{[0.562]}\end{array}$ & & $\begin{array}{c}0.109 \\
{[0.457]}\end{array}$ \\
\hline $\mathrm{HO}$ & $\begin{array}{c}0.518 \\
{[0.595]}\end{array}$ & $\begin{array}{c}0.517 \\
{[0.607]}\end{array}$ & $\begin{array}{c}0.513 \\
{[0.655]}\end{array}$ & $\begin{array}{c}-0.034 \\
(0.089)\end{array}$ & $\begin{array}{c}0.048 \\
(0.055)\end{array}$ & $\begin{array}{r}0.0 \\
(0.0\end{array}$ & $\begin{array}{c}-0.869 \\
{[0.808]}\end{array}$ & $\begin{array}{c}-0.215 \\
{[0.585]}\end{array}$ & \\
\hline JY & $\begin{array}{c}0.558 \\
{[0.085]}\end{array}$ & $\begin{array}{c}0.555 \\
{[0.113]}\end{array}$ & $\begin{array}{c}0.558 \\
{[0.085]}\end{array}$ & $\begin{array}{c}0.056 \\
(0.076)\end{array}$ & $\begin{array}{r}0.1 \\
(0.0\end{array}$ & & & & $\begin{array}{c}2.834 \\
{[0.002]}\end{array}$ \\
\hline $\mathrm{KC}$ & $\begin{array}{c}0.499 \\
{[0.831]}\end{array}$ & $\begin{array}{c}0.502 \\
{[0.797]}\end{array}$ & $\begin{array}{r}0.50 \\
0.8\end{array}$ & $\begin{array}{r}0.0 \\
(0.0\end{array}$ & $\begin{array}{r}-0.0 \\
(0.0\end{array}$ & & & $\begin{array}{c}-0.343 \\
{[0.634]}\end{array}$ & $\begin{array}{c}-0.127 \\
{[0.551]}\end{array}$ \\
\hline LC & $\begin{array}{c}0.510 \\
{[0.700]}\end{array}$ & $\begin{array}{c}0.509 \\
{[0.715]}\end{array}$ & $\begin{array}{c}0.508 \\
{[0.725]}\end{array}$ & & $\begin{array}{c}-0.078 \\
(0.055)\end{array}$ & $\begin{array}{c}-0.095 \\
(0.061)\end{array}$ & & $\begin{array}{c}-0.826 \\
{[0.796]}\end{array}$ & $\begin{array}{c}-1.707 \\
{[0.956]}\end{array}$ \\
\hline LH & & $\begin{array}{c}0.502 \\
{[0.797]}\end{array}$ & $\begin{array}{c}0.500 \\
{[0.826]}\end{array}$ & & & & & & \\
\hline JO & $\begin{array}{c}0.520 \\
{[0.550]}\end{array}$ & $\begin{array}{c}0.520 \\
{[0.560]}\end{array}$ & $\begin{array}{c}0.518 \\
{[0.584]}\end{array}$ & $\begin{array}{c}-0.091 \\
(0.092)\end{array}$ & $\begin{array}{r}-0.098 \\
(0.056)\end{array}$ & $\begin{array}{r}-0.049 \\
(0.062)\end{array}$ & $\begin{array}{c}-0.657 \\
{[0.744]}\end{array}$ & $\begin{array}{c}-1.568 \\
{[0.942]}\end{array}$ & $\begin{array}{c}-1.247 \\
{[0.894]}\end{array}$ \\
\hline PB & $\begin{array}{c}0.501 \\
{[0.814]}\end{array}$ & $\begin{array}{c}0.488 \\
{[0.919]}\end{array}$ & $\begin{array}{c}0.490 \\
{[0.910]}\end{array}$ & $\begin{array}{c}-0.104 \\
(0.080)\end{array}$ & $\begin{array}{c}-0.069 \\
(0.060)\end{array}$ & $\begin{array}{c}-0.077 \\
(0.067)\end{array}$ & $\begin{array}{c}-0.751 \\
{[0.774]}\end{array}$ & $\begin{array}{c}-0.973 \\
{[0.835]}\end{array}$ & $\begin{array}{c}-1.235 \\
{[0.892]}\end{array}$ \\
\hline JS & $\begin{array}{c}0.487 \\
{[0.926]}\end{array}$ & $\begin{array}{c}0.491 \\
{[0.905]}\end{array}$ & $\begin{array}{c}0.487 \\
{[0.930]}\end{array}$ & $\begin{array}{r}-0.040 \\
(0.075)\end{array}$ & $\begin{array}{c}0.074 \\
(0.053)\end{array}$ & $\begin{array}{c}0.122 \\
(0.058)\end{array}$ & $\begin{array}{c}-0.148 \\
{[0.559]}\end{array}$ & $\begin{array}{c}0.933 \\
{[0.175]}\end{array}$ & $\begin{array}{c}1.456 \\
{[0.073]}\end{array}$ \\
\hline SB & $\begin{array}{c}0.513 \\
{[0.658]}\end{array}$ & $\begin{array}{c}0.519 \\
{[0.569]}\end{array}$ & $\begin{array}{c}0.511 \\
{[0.681]}\end{array}$ & $\begin{array}{r}-0.0 \\
(0.0\end{array}$ & $\begin{array}{c}-0.013 \\
(0.051)\end{array}$ & $\begin{array}{r}0.0 \\
(0.0\end{array}$ & $\begin{array}{c}-0.412 \\
{[0.660]}\end{array}$ & $\begin{array}{c}-0.012 \\
{[0.505]}\end{array}$ & $\begin{array}{c}-0.767 \\
{[0.779]}\end{array}$ \\
\hline SF & $\begin{array}{c}0.544 \\
{[0.209]}\end{array}$ & $\begin{array}{c}0.542 \\
{[0.232]}\end{array}$ & $\begin{array}{c}0.544 \\
{[0.216]}\end{array}$ & $\begin{array}{c}0.007 \\
(0.085)\end{array}$ & $\begin{array}{c}0.016 \\
(0.048)\end{array}$ & $\begin{array}{c}0.024 \\
(0.054)\end{array}$ & $\begin{array}{c}0.905 \\
{[0.183]}\end{array}$ & $\begin{array}{c}0.863 \\
{[0.194]}\end{array}$ & $\begin{array}{c}1.542 \\
{[0.062]}\end{array}$ \\
\hline SI & $\begin{array}{c}0.556 \\
{[0.102]}\end{array}$ & $\begin{array}{c}0.550 \\
{[0.149]}\end{array}$ & $\begin{array}{c}0.551 \\
{[0.143]}\end{array}$ & $\begin{array}{c}0.006 \\
(0.067)\end{array}$ & $\begin{array}{c}0.101 \\
(0.045)\end{array}$ & $\begin{array}{c}0.107 \\
(0.050)\end{array}$ & $\begin{array}{c}0.217 \\
{[0.414]}\end{array}$ & & $\begin{array}{c}1.628 \\
{[0.052]}\end{array}$ \\
\hline SM & $\begin{array}{c}0.505 \\
{[0.769]}\end{array}$ & $\begin{array}{c}0.505 \\
{[0.765]}\end{array}$ & $\begin{array}{c}0.503 \\
{[0.790]}\end{array}$ & $\begin{array}{c}-0.022 \\
(0.084)\end{array}$ & $\begin{array}{c}0.035 \\
(0.054)\end{array}$ & $\begin{array}{c}0.084 \\
(0.060)\end{array}$ & $\begin{array}{c}-0.205 \\
{[0.581]}\end{array}$ & $\begin{array}{c}0.349 \\
{[0.364]}\end{array}$ & $\begin{array}{c}0.694 \\
{[0.244]}\end{array}$ \\
\hline SP & $\begin{array}{c}0.497 \\
{[0.848]}\end{array}$ & $\begin{array}{c}0.505 \\
{[0.762]}\end{array}$ & $\begin{array}{c}0.497 \\
{[0.848]}\end{array}$ & $\begin{array}{c}-0.001 \\
(0.091)\end{array}$ & $\begin{array}{c}-0.080 \\
(0.051)\end{array}$ & $\begin{array}{c}-0.107 \\
(0.058)\end{array}$ & $\begin{array}{c}-0.525 \\
{[0.700]}\end{array}$ & $\begin{array}{c}-0.446 \\
{[0.672]}\end{array}$ & $\begin{array}{c}-1.650 \\
{[0.951]}\end{array}$ \\
\hline JW & $\begin{array}{c}0.532 \\
{[0.370]}\end{array}$ & $\begin{array}{c}0.532 \\
{[0.366]}\end{array}$ & $\begin{array}{c}0.531 \\
{[0.384]}\end{array}$ & $\begin{array}{c}-0.025 \\
(0.079)\end{array}$ & $\begin{array}{c}-0.024 \\
(0.048)\end{array}$ & $\begin{array}{c}0.010 \\
(0.053)\end{array}$ & $\begin{array}{c}-0.551 \\
{[0.709]}\end{array}$ & $\begin{array}{c}-0.375 \\
{[0.646]}\end{array}$ & $\begin{array}{c}-0.880 \\
{[0.811]}\end{array}$ \\
\hline
\end{tabular}

Values in brackets below the estimates for $J$ (Hurst estimates) and below the statistics $t$ (LM test) are the $p$ values for the one-sided test for persistent long memory. Values in parentheses below the estimates for $d$ (GPH estimates) are the standard errors for the estimates. 


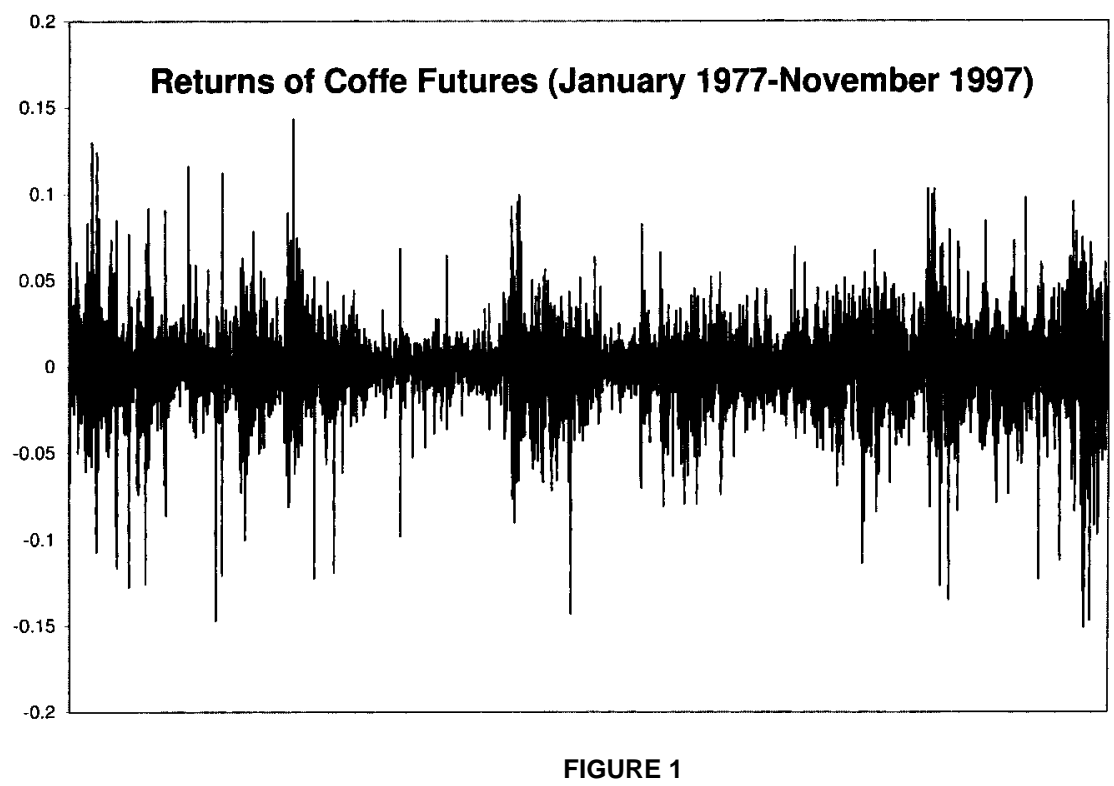

Futures returns display a very noisy behavior. As the example in the graph shows, it is difficult to detect any structure in the direction of change.

of $J>0.5$, i.e., they suggest the presence of long memory. However, the $p$ values for the corrected estimates all are high, well above the conventional significance values for statistical testing. At 1, 5, and even 10\%, one cannot reject the null of short memory, $J=0$, for any of the time series. The GPH method gives estimates of $d$ oscillating about zero, with standard errors of the same order as the estimates. None of the $t$ tests rejects the hypothesis $d=0$, confirming the results of the modified $\mathrm{R} / \mathrm{S}$ analysis. The third approach confirms these results. In all cases, the values of the statistic are close to zero, and the corresponding $p$ values are high, well above the conventinal thresholds for significance.

The three methods provide a consistent indication of no long memory for the returns.

Findings for the extended data set, given in Table II, are based on much longer series and corroborate these findings. An example of returns of such a data series is shown in Figure 1. The corresponding sample autocorrelations are shown in Figure 2. A simple graphical analysis of these two figures suggests that there is no significant memory on the series of returns. It is not surprising that the corrected $\mathrm{R} / \mathrm{S}(q \neq 0)$ statistic, the GPH tests, and the LM tests reject unequivocally the existence of long memory. Using the classical R/S statistic $(q=0)$, short memory is rejected for several series, although the estimated values of the Hurst exponent are only slightly larger than 0.5 . Using the GPH and the LM 


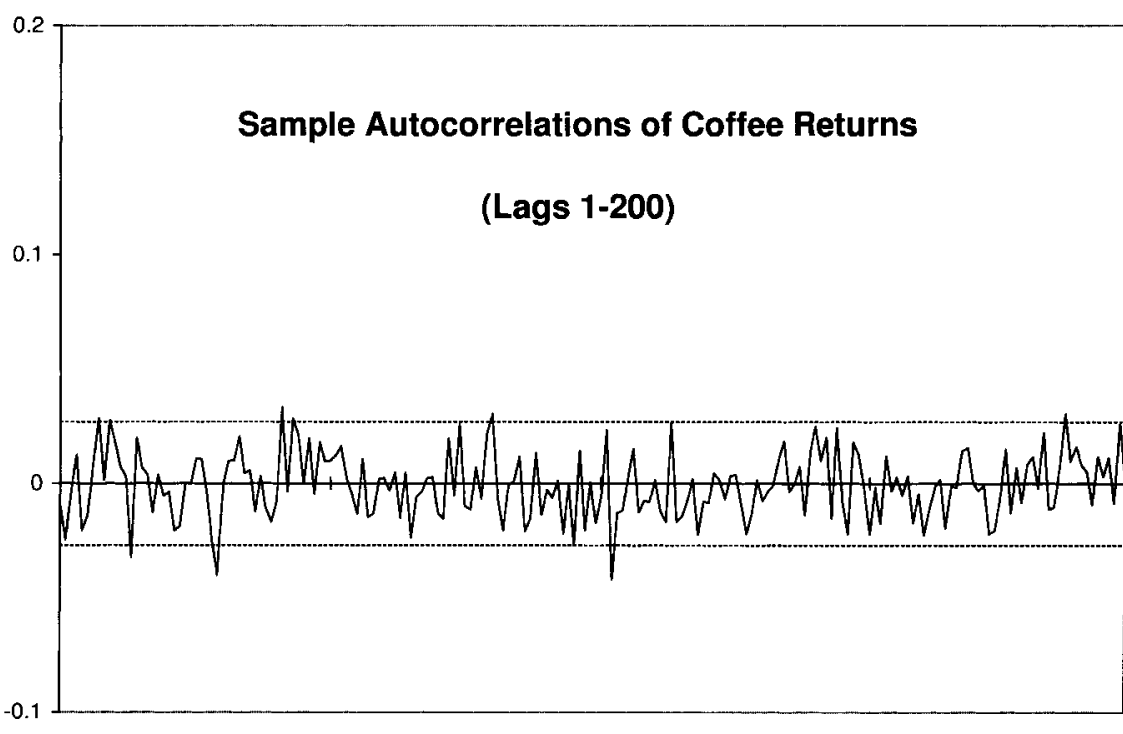

FIGURE 2

The autocorrelations of futures returns display the characteristic behavior of a process with no memory. Most of the sample values, 95\% or more, fall inside the $95 \%$ confidence bands constructed under the null of an uncorrelated process.

tests, only in a few cases are there some apparently significant values. However, since 23 series are analyzed and six tests are conducted for each case, one or two apparently significant values should be taken as natural results of the random error due to the repetition of the same tests. Nevertheless, there is not a single case in which the different methods and different truncations simultaneously point to long memory.

The results are very clear: The indication of long memory given by the classical $\mathrm{R} / \mathrm{S}$ is a statistical artifact of the short-range correlations present in the data.

\section{TESTING FOR LONG MEMORY IN VOLATILITY OF FUTURES' RETURNS}

Although the lack of long memory in the movement of financial markets currently is well accepted, more recent research has focused on the existence of persistent behavior in the volatility of financial markets. Evidence of long-range dependence in volatilities has been found by many authors, including Ding et al. (1993), de Lima and Crato (1993), Bollerslev and Mikkelsen (1996), Baillie et al. (1996), Breidt et al. (1998), and Lobato and Savin (1998). However, a study of persistence in futures' volatility has not yet been presented in the literature. This analysis is important for forecasting, risk assessment, and portfolio optimization. 


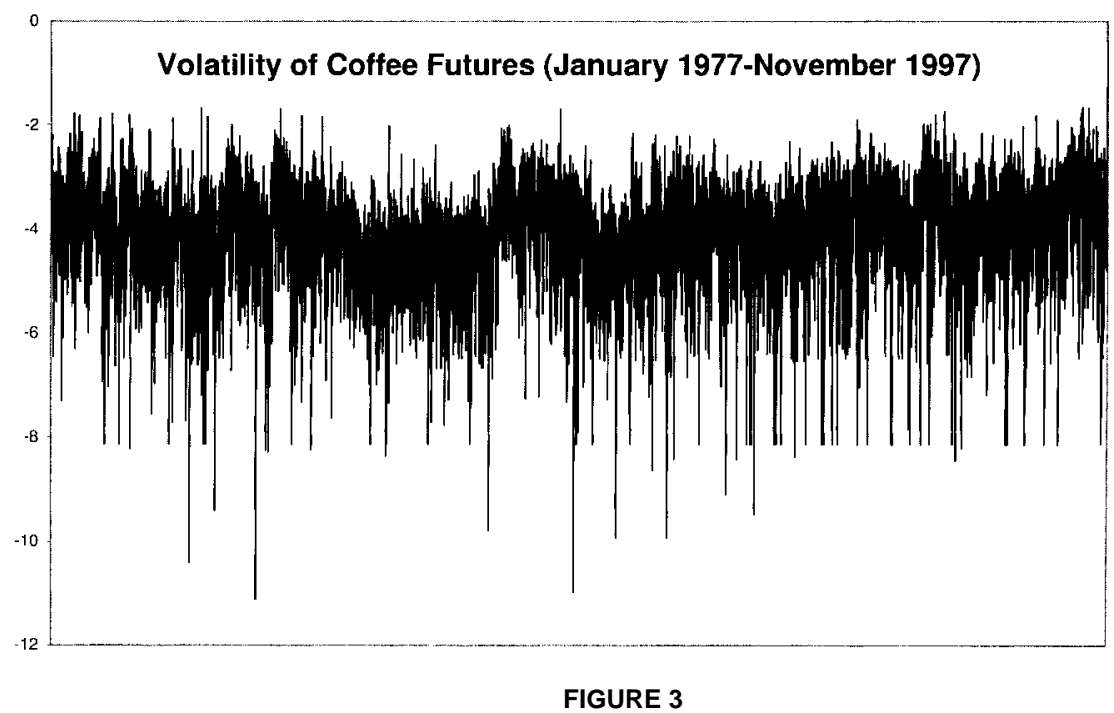

Futures volatility series display an unmistakable memory structure, with long nonperiodic waves characteristic of a long-memory process. Periods of high volatility are likely to be followed by periods of high volatility and periods of low volatility by periods of low volatility.

Various measures of volatility can be constructed, in particular the absolute value of returns, the square of returns, and the logarithm of the squared returns. Empirical findings indicate that evidence concerning long-range dependence is essentially the same for all these measures (see Breidt et al. 1998). This study analyzes the series of logarithms of the mean-corrected returns, $r_{t}=\log \left(r_{t}^{*}-\bar{r}^{*}\right)^{2}$, using the same three tests applied in the the previous section. Breidt et al. (1998) and Deo and Hurvich (1998) study the behavior of these tests for the detection of long memory in volatility data.

Figure 3 shows an example of such a volatility series. A simple graphical analysis reveals an interesting pattern, completely different from the one displayed by the series of returns. Underneath the natural variability, there are apparent slow movements on the volatility levels.

Tables III and IV present the formal testing results for all the futures' contract volatility series. The contrast between the analysis of the returns and of the volatilities is striking. While returns do not display persistence, the volatilities show a strong and significant persistence for almost all studied series. For the Helms data, the only exceptions are two of the shorter series, soybeans for March 77 (BO M76) and soybean meal for the same date (SM M76), which have conflicting evidence of long-memory. Results for the extended data set, shown in Table IV, consistently indicate significant long-memory behavior. 
TABLE III

Memory Estimates for the Helms Data Volatility

\begin{tabular}{|c|c|c|c|c|c|c|c|c|c|}
\hline \multirow[b]{2}{*}{ Series } & \multicolumn{3}{|c|}{$\begin{array}{c}\text { Hurst } \\
\text { Estimates } \hat{J}\end{array}$} & \multicolumn{3}{|c|}{$\begin{array}{c}\text { GPH } \\
\text { Estimates } \hat{d}\end{array}$} & \multicolumn{3}{|c|}{$\begin{array}{c}\text { Nonparametric } \\
\text { LM Test }\end{array}$} \\
\hline & $q=0$ & $q=5$ & $q=q^{*}$ & $\begin{array}{c}m=\left[n^{0.50}\right] \\
l=1\end{array}$ & $\begin{array}{c}m=\left[n^{0.60}\right] \\
l=1\end{array}$ & $\begin{array}{c}m=\left[n^{0.60}\right] \\
l=2\end{array}$ & $m=\left[n^{.50}\right]$ & $m=\left[n^{.55}\right]$ & $m=\left[n^{.60}\right]$ \\
\hline BO M76 & $\begin{array}{c}0.600 \\
{[0.050]}\end{array}$ & $\begin{array}{c}0.585 \\
{[0.109]}\end{array}$ & $\begin{array}{c}0.604 \\
{[0.040]}\end{array}$ & $\begin{array}{c}0.162 \\
(0.149)\end{array}$ & $\begin{array}{c}0.158 \\
(0.149)\end{array}$ & $\begin{array}{c}0.382 \\
(0.151)\end{array}$ & $\begin{array}{c}1.737 \\
{[0.040]}\end{array}$ & $\begin{array}{c}1.400 \\
{[0.081]}\end{array}$ & $\begin{array}{c}2.328 \\
{[0.010]}\end{array}$ \\
\hline BO J77 & $\begin{array}{c}0.706 \\
{[0.000]}\end{array}$ & $\begin{array}{c}0.658 \\
{[0.001]}\end{array}$ & $\begin{array}{c}0.700 \\
{[0.000]}\end{array}$ & $\begin{array}{c}0.459 \\
(0.168)\end{array}$ & $\begin{array}{c}0.193 \\
(0.110)\end{array}$ & $\begin{array}{c}0.172 \\
(0.137)\end{array}$ & $\begin{array}{c}3.870 \\
{[0.000]}\end{array}$ & $\begin{array}{c}4.650 \\
{[0.000]}\end{array}$ & $\begin{array}{c}4.853 \\
{[0.000]}\end{array}$ \\
\hline SO M76 & $\begin{array}{c}0.615 \\
{[0.018]}\end{array}$ & $\begin{array}{c}0.584 \\
{[0.108]}\end{array}$ & $\begin{array}{c}0.602 \\
{[0.041]}\end{array}$ & $\begin{array}{c}0.454 \\
(0.165)\end{array}$ & $\begin{array}{c}0.347 \\
(0.123)\end{array}$ & $\begin{array}{c}0.412 \\
(0.123)\end{array}$ & $\begin{array}{c}2.029 \\
{[0.020]}\end{array}$ & $\begin{array}{c}2.604 \\
{[0.005]}\end{array}$ & $\begin{array}{c}3.157 \\
{[0.001]}\end{array}$ \\
\hline SO J77 & $\begin{array}{c}0.711 \\
{[0.000]}\end{array}$ & $\begin{array}{c}0.673 \\
{[0.000]}\end{array}$ & $\begin{array}{c}0.692 \\
{[0.000]}\end{array}$ & $\begin{array}{c}0.454 \\
(0.165)\end{array}$ & $\begin{array}{c}0.347 \\
(0.123)\end{array}$ & $\begin{array}{c}-0.001 \\
(0.116)\end{array}$ & $\begin{array}{c}4.894 \\
{[0.000]}\end{array}$ & $\begin{array}{c}5.413 \\
{[0.000]}\end{array}$ & $\begin{array}{c}5.767 \\
{[0.000]}\end{array}$ \\
\hline SM M76 & $\begin{array}{c}0.597 \\
{[0.073]}\end{array}$ & $\begin{array}{c}0.581 \\
{[0.142]}\end{array}$ & $\begin{array}{c}0.590 \\
{[0.098]}\end{array}$ & $\begin{array}{c}0.162 \\
(0.149)\end{array}$ & $\begin{array}{c}0.158 \\
(0.149)\end{array}$ & $\begin{array}{c}0.077 \\
(0.184)\end{array}$ & $\begin{array}{c}0.572 \\
{[0.280]}\end{array}$ & $\begin{array}{c}0.158 \\
{[0.437]}\end{array}$ & $\begin{array}{c}0.592 \\
{[0.277]}\end{array}$ \\
\hline SM J77 & $\begin{array}{c}0.728 \\
{[0.000]}\end{array}$ & $\begin{array}{c}0.659 \\
{[0.000]}\end{array}$ & $\begin{array}{c}0.659 \\
{[0.000]}\end{array}$ & $\begin{array}{c}0.459 \\
(0.168)\end{array}$ & $\begin{array}{c}0.193 \\
(0.110)\end{array}$ & $\begin{array}{c}0.179 \\
(0.191)\end{array}$ & $\begin{array}{c}4.277 \\
{[0.000]}\end{array}$ & $\begin{array}{c}5.295 \\
{[0.000]}\end{array}$ & $\begin{array}{c}5.953 \\
{[0.000]}\end{array}$ \\
\hline
\end{tabular}

Returns volatility is computed as the series of logs of mean-corrected squared returns. Values in brackets below the estimates for $J$ (Hurst estimates) and below the statistics $t$ (LM test) are the $p$ values for the one-sided test for persistent long memory. Values in parentheses below the estimates for $d$ (GPH estimates) are the standard errors for the estimates.

It is interesting to note from Table IV that the persistence showed by the commodity futures' volatility is substantially higher than the persistence shown by the currency futures' volatility. Higher estimates for the memory parameters $J$ and $d$ and higher values of the LM statistic $t$ indicate more persistent memory in the time series. With the exception of the British Pound (BP), the estimates for the commodity futures are substantially higher than the estimates for the currency futures. This means that shocks driving volatility persist longer, on average, on the commodity futures' transactions. Markets seem to absorb more quickly the instability in currency futures than in commodity futures.

\section{A VOLATILITY MODEL FOR FUTURES DATA}

Breidt et al. (1998) introduced the long-memory-stochastic-volatility (LMSV) model to describe the type of persistent-dependence structure observed for the futures' volatility series. The model is an extension of the short-range-dependent-stochastic-volatility model of Melino and Turnbull (1990) and Harvey, Ruiz, and Shephard (1994), which has been 
TABLE IV

Memory Estimates for the Extended Data Volatility

\begin{tabular}{|c|c|c|c|c|c|c|c|c|c|}
\hline \multirow[b]{2}{*}{ Series } & \multicolumn{3}{|c|}{$\begin{array}{c}\text { Hurst } \\
\text { Estimates } \hat{J}\end{array}$} & \multicolumn{3}{|c|}{$\begin{array}{c}\text { GPH } \\
\text { Estimates } \hat{d}\end{array}$} & \multicolumn{3}{|c|}{$\begin{array}{c}\text { Nonparametric } \\
\text { LM Test }\end{array}$} \\
\hline & $q=0$ & $q=5$ & $q=q^{*}$ & $\begin{array}{c}m=\left[n^{0.50}\right] \\
l=1\end{array}$ & $\begin{array}{c}m=\left[n^{0.60}\right] \\
l=1\end{array}$ & $\begin{array}{c}m=\left[n^{0.60}\right] \\
l=3\end{array}$ & $m=\left[n^{.50}\right]$ & $m=\left[n^{.55}\right]$ & $m=\left[n^{.60}\right]$ \\
\hline $\mathrm{BO}$ & $\begin{array}{c}0.697 \\
{[0.000]}\end{array}$ & $\begin{array}{c}0.663 \\
{[0.000]}\end{array}$ & $\begin{array}{c}0.678 \\
{[0.000]}\end{array}$ & & & & & & \\
\hline $\mathrm{BP}$ & $\begin{array}{c}0.732 \\
{[0.000]}\end{array}$ & $\begin{array}{c}0.686 \\
{[0.000]}\end{array}$ & $\begin{array}{c}0.693 \\
{[0.000]}\end{array}$ & $\begin{array}{c}0.627 \\
(0.073)\end{array}$ & $\begin{array}{c}0.384 \\
(0.047)\end{array}$ & $\begin{array}{c}0.345 \\
(0.052)\end{array}$ & $\begin{array}{l}13.123 \\
{[0.000]}\end{array}$ & $\begin{array}{l}17.258 \\
{[0.000]}\end{array}$ & $\begin{array}{l}21.944 \\
{[0.000]}\end{array}$ \\
\hline $\mathrm{JC}$ & $\begin{array}{c}0.642 \\
{[0.000]}\end{array}$ & $\begin{array}{c}0.594 \\
{[0.002]}\end{array}$ & $\begin{array}{c}0.601 \\
{[0.001]}\end{array}$ & $\begin{array}{c}0.339 \\
(0.090)\end{array}$ & $\begin{array}{c}0.359 \\
(0.056)\end{array}$ & $\begin{array}{c}0.414 \\
(0.061)\end{array}$ & $\begin{array}{c}4.600 \\
{[0.000]}\end{array}$ & $\begin{array}{l}7.908 \\
{[0.000]}\end{array}$ & $\begin{array}{l}12.156 \\
{[0.000]}\end{array}$ \\
\hline$C D$ & $\begin{array}{c}0.643 \\
{[0.000]}\end{array}$ & $\begin{array}{c}0.608 \\
{[0.000]}\end{array}$ & $\begin{array}{c}0.619 \\
{[0.000]}\end{array}$ & $\begin{array}{c}0.424 \\
(0.071)\end{array}$ & $\begin{array}{c}0.323 \\
(0.049)\end{array}$ & $\begin{array}{c}0.337 \\
(0.055)\end{array}$ & $\begin{array}{c}6.251 \\
{[0.000]}\end{array}$ & $\begin{array}{c}8.694 \\
{[0.000]}\end{array}$ & $\begin{array}{l}11.219 \\
{[0.000]}\end{array}$ \\
\hline $\mathrm{CT}$ & $\begin{array}{c}0.663 \\
{[0.000]}\end{array}$ & $\begin{array}{c}0.627 \\
{[0.000]}\end{array}$ & $\begin{array}{c}0.634 \\
{[0.000]}\end{array}$ & $\begin{array}{c}0.363 \\
(0.071)\end{array}$ & $\begin{array}{c}0.269 \\
(0.045)\end{array}$ & $\begin{array}{c}0.293 \\
(0.050)\end{array}$ & $\begin{array}{c}7.201 \\
{[0.000]}\end{array}$ & $\begin{array}{c}9.213 \\
{[0.000]}\end{array}$ & $\begin{array}{l}11.230 \\
{[0.000]}\end{array}$ \\
\hline DM & $\begin{array}{c}0.699 \\
{[0.000]}\end{array}$ & $\begin{array}{c}0.666 \\
{[0.000]}\end{array}$ & $\begin{array}{c}0.681 \\
{[0.000]}\end{array}$ & $\begin{array}{c}0.444 \\
(0.066)\end{array}$ & $\begin{array}{c}0.395 \\
(0.046)\end{array}$ & $\begin{array}{c}0.381 \\
(0.052)\end{array}$ & $\begin{array}{c}9.156 \\
{[0.000]}\end{array}$ & $\begin{array}{l}11.050 \\
{[0.000]}\end{array}$ & $\begin{array}{l}15.189 \\
{[0.000]}\end{array}$ \\
\hline FC & $\begin{array}{c}0.772 \\
{[0.000]}\end{array}$ & $\begin{array}{c}0.718 \\
{[0.000]}\end{array}$ & $\begin{array}{c}0.721 \\
{[0.000]}\end{array}$ & $\begin{array}{c}0.342 \\
(0.082)\end{array}$ & $\begin{array}{c}0.349 \\
(0.048)\end{array}$ & & $\begin{array}{l}15.576 \\
{[0.000]}\end{array}$ & $\begin{array}{l}21.068 \\
{[0.000]}\end{array}$ & $\begin{array}{l}27.603 \\
{[0.000]}\end{array}$ \\
\hline GC & $\begin{array}{c}0.787 \\
{[0.000]}\end{array}$ & $\begin{array}{c}0.721 \\
{[0.000]}\end{array}$ & $\begin{array}{c}0.717 \\
{[0.000]}\end{array}$ & $\begin{array}{c}0.607 \\
(0.078)\end{array}$ & $\begin{array}{c}0.385 \\
(0.050)\end{array}$ & & & & \\
\hline$H G$ & $\begin{array}{c}0.691 \\
{[0.000]}\end{array}$ & $\begin{array}{c}0.651 \\
{[0.000]}\end{array}$ & $\begin{array}{c}0.660 \\
{[0.000]}\end{array}$ & & $\begin{array}{c}0.335 \\
(0.048)\end{array}$ & & & & $\begin{array}{l}19.366 \\
{[0.000]}\end{array}$ \\
\hline $\mathrm{HO}$ & $\begin{array}{c}0.734 \\
{[0.000]}\end{array}$ & $\begin{array}{c}0.677 \\
{[0.000]}\end{array}$ & $\begin{array}{c}0.677 \\
{[0.000]}\end{array}$ & $\begin{array}{c}0.506 \\
(0.082)\end{array}$ & $\begin{array}{c}0.490 \\
(0.051)\end{array}$ & $\begin{array}{c}0.486 \\
(0.058)\end{array}$ & $\begin{array}{c}9.584 \\
{[0.000]}\end{array}$ & $\begin{array}{l}13.485 \\
{[0.000]}\end{array}$ & $\begin{array}{l}19.143 \\
{[0.000]}\end{array}$ \\
\hline JY & $\begin{array}{c}0.661 \\
{[0.000]}\end{array}$ & $\begin{array}{c}0.629 \\
{[0.000]}\end{array}$ & $\begin{array}{c}0.638 \\
{[0.000]}\end{array}$ & $\begin{array}{c}0.259 \\
(0.084)\end{array}$ & $\begin{array}{c}0.258 \\
(0.048)\end{array}$ & $\begin{array}{c}0.279 \\
(0.052)\end{array}$ & $\begin{array}{c}5.855 \\
{[0.000]}\end{array}$ & $\begin{array}{c}7.328 \\
{[0.000]}\end{array}$ & $\begin{array}{l}10.661 \\
{[0.000]}\end{array}$ \\
\hline $\mathrm{KC}$ & $\begin{array}{c}0.714 \\
{[0.000]}\end{array}$ & $\begin{array}{c}0.663 \\
{[0.000]}\end{array}$ & $\begin{array}{c}0.666 \\
{[0.000]}\end{array}$ & $\begin{array}{c}0.424 \\
(0.096)\end{array}$ & $\begin{array}{c}0.393 \\
(0.059)\end{array}$ & $\begin{array}{c}0.378 \\
(0.066)\end{array}$ & $\begin{array}{c}9.510 \\
{[0.000]}\end{array}$ & $\begin{array}{l}13.264 \\
{[0.000]}\end{array}$ & $\begin{array}{l}17.352 \\
{[0.000]}\end{array}$ \\
\hline LC & $\begin{array}{c}0.739 \\
{[0.000]}\end{array}$ & $\begin{array}{c}0.701 \\
{[0.000]}\end{array}$ & $\begin{array}{c}0.713 \\
{[0.000]}\end{array}$ & $\begin{array}{c}0.498 \\
(0.080)\end{array}$ & $\begin{array}{c}0.339 \\
(0.052)\end{array}$ & $\begin{array}{c}0.294 \\
(0.058)\end{array}$ & $\begin{array}{l}14.911 \\
{[0.000]}\end{array}$ & $\begin{array}{l}19.177 \\
{[0.000]}\end{array}$ & $\begin{array}{c}23.732 \\
{[0.000]}\end{array}$ \\
\hline $\mathrm{LH}$ & $\begin{array}{c}0.714 \\
{[0.000]}\end{array}$ & $\begin{array}{c}0.663 \\
{[0.000]}\end{array}$ & $\begin{array}{c}0.666 \\
{[0.000]}\end{array}$ & $\begin{array}{c}0.424 \\
(0.096)\end{array}$ & $\begin{array}{c}0.393 \\
(0.059)\end{array}$ & $\begin{array}{r}0.3 \\
0.0\end{array}$ & $\begin{array}{r}9.5 \\
{[0.0}\end{array}$ & $\begin{array}{l}13.264 \\
{[0.000]}\end{array}$ & $\begin{array}{l}17.352 \\
{[0.000]}\end{array}$ \\
\hline JO & $\begin{array}{c}0.637 \\
{[0.000]}\end{array}$ & $\begin{array}{c}0.597 \\
{[0.000]}\end{array}$ & $\begin{array}{c}0.602 \\
{[0.000]}\end{array}$ & $\begin{array}{c}0.428 \\
(0.105)\end{array}$ & $\begin{array}{c}0.263 \\
(0.056)\end{array}$ & $\begin{array}{c}0.285 \\
(0.061)\end{array}$ & & $\begin{array}{c}9.056 \\
{[0.000]}\end{array}$ & $\begin{array}{l}12.055 \\
{[0.000]}\end{array}$ \\
\hline PB & $\begin{array}{c}0.657 \\
{[0.000]}\end{array}$ & $\begin{array}{c}0.630 \\
{[0.000]}\end{array}$ & $\begin{array}{c}0.643 \\
{[0.000]}\end{array}$ & $\begin{array}{c}0.303 \\
(0.088)\end{array}$ & $\begin{array}{c}0.242 \\
(0.052)\end{array}$ & $\begin{array}{c}0.202 \\
(0.057)\end{array}$ & $\begin{array}{c}5.741 \\
{[0.000]}\end{array}$ & $\begin{array}{c}8.042 \\
{[0.000]}\end{array}$ & $\begin{array}{l}11.105 \\
{[0.000]}\end{array}$ \\
\hline JS & $\begin{array}{c}0.717 \\
{[0.000]}\end{array}$ & $\begin{array}{c}0.670 \\
{[0.000]}\end{array}$ & $\begin{array}{c}0.680 \\
{[0.000]}\end{array}$ & $\begin{array}{c}0.397 \\
(0.080)\end{array}$ & $\begin{array}{c}0.408 \\
(0.052)\end{array}$ & $\begin{array}{c}0.386 \\
(0.058)\end{array}$ & $\begin{array}{c}9.156 \\
{[0.000]}\end{array}$ & $\begin{array}{l}13.183 \\
{[0.000]}\end{array}$ & $\begin{array}{l}18.259 \\
{[0.000]}\end{array}$ \\
\hline SB & $\begin{array}{c}0.774 \\
{[0.000]}\end{array}$ & $\begin{array}{c}0.722 \\
{[0.000]}\end{array}$ & $\begin{array}{c}0.722 \\
{[0.000]}\end{array}$ & $\begin{array}{c}0.468 \\
(0.092)\end{array}$ & $\begin{array}{c}0.292 \\
(0.053)\end{array}$ & $\begin{array}{c}0.229 \\
(0.058)\end{array}$ & $\begin{array}{l}17.011 \\
{[0.000]}\end{array}$ & $\begin{array}{c}20.767 \\
{[0.000]}\end{array}$ & $\begin{array}{c}26.254 \\
{[0.000]}\end{array}$ \\
\hline SF & $\begin{array}{c}0.672 \\
{[0.000]}\end{array}$ & $\begin{array}{c}0.646 \\
{[0.000]}\end{array}$ & $\begin{array}{c}0.661 \\
{[0.000]}\end{array}$ & $\begin{array}{c}0.441 \\
(0.079)\end{array}$ & $\begin{array}{c}0.389 \\
(0.054)\end{array}$ & $\begin{array}{c}0.382 \\
(0.060)\end{array}$ & $\begin{array}{c}8.216 \\
{[0.000]}\end{array}$ & $\begin{array}{l}11.005 \\
{[0.000]}\end{array}$ & $\begin{array}{l}15.066 \\
{[0.000]}\end{array}$ \\
\hline SI & $\begin{array}{c}0.751 \\
{[0.000]}\end{array}$ & $\begin{array}{c}0.700 \\
{[0.000]}\end{array}$ & $\begin{array}{c}0.703 \\
{[0.000]}\end{array}$ & $\begin{array}{c}0.488 \\
(0.088)\end{array}$ & $\begin{array}{c}0.368 \\
(0.052)\end{array}$ & $\begin{array}{c}0.320 \\
(0.057)\end{array}$ & $\begin{array}{l}14.114 \\
{[0.000]}\end{array}$ & $\begin{array}{l}19.245 \\
{[0.000]}\end{array}$ & $\begin{array}{l}24.743 \\
{[0.000]}\end{array}$ \\
\hline SM & $\begin{array}{c}0.697 \\
{[0.000]}\end{array}$ & $\begin{array}{c}0.652 \\
{[0.000]}\end{array}$ & $\begin{array}{c}0.658 \\
{[0.000]}\end{array}$ & $\begin{array}{c}0.300 \\
(0.085)\end{array}$ & $\begin{array}{c}0.309 \\
(0.046)\end{array}$ & $\begin{array}{c}0.277 \\
(0.051)\end{array}$ & $\begin{array}{c}7.944 \\
{[0.000]}\end{array}$ & $\begin{array}{l}11.597 \\
{[0.000]}\end{array}$ & $\begin{array}{l}15.288 \\
{[0.000]}\end{array}$ \\
\hline SP & $\begin{array}{c}0.708 \\
{[0.000]}\end{array}$ & $\begin{array}{c}0.673 \\
{[0.000]}\end{array}$ & $\begin{array}{c}0.693 \\
{[0.000]}\end{array}$ & $\begin{array}{c}0.625 \\
(0.089)\end{array}$ & $\begin{array}{c}0.378 \\
(0.055)\end{array}$ & $\begin{array}{c}0.335 \\
(0.062)\end{array}$ & $\begin{array}{l}11.430 \\
{[0.000]}\end{array}$ & $\begin{array}{l}14.381 \\
{[0.000]}\end{array}$ & $\begin{array}{l}18.323 \\
{[0.000]}\end{array}$ \\
\hline JW & $\begin{array}{c}0.632 \\
{[0.000]}\end{array}$ & $\begin{array}{c}0.609 \\
{[0.000]}\end{array}$ & $\begin{array}{c}0.622 \\
{[0.000]}\end{array}$ & $\begin{array}{c}0.230 \\
(0.082)\end{array}$ & $\begin{array}{c}0.208 \\
(0.048)\end{array}$ & $\begin{array}{c}0.206 \\
(0.054)\end{array}$ & $\begin{array}{c}5.130 \\
{[0.000]}\end{array}$ & $\begin{array}{c}6.521 \\
{[0.000]}\end{array}$ & $\begin{array}{c}8.704 \\
{[0.000]}\end{array}$ \\
\hline
\end{tabular}

The volatility is computed as the series of logs of mean-corrected squared returns. Values in brackets below the estimates for $J$ (Hurst estimates) and below the statistics $t$ (LM test) are the $p$ values for the one-sided test for persistent long memory. Values in parentheses below the estimates for $d$ (GPH estimates) are the standard errors for the estimates. 
used to describe the behavior of log squared stock returns. A LMSV process is defined by

$$
r_{t}=\sigma_{t} \psi_{t}, \sigma_{t}=\sigma \exp \left(v_{t} / 2\right)
$$

where $\sigma>0,\left\{v_{t}\right\}$ is independent of $\left\{\psi_{t}\right\},\left\{\psi_{t}\right\}$ is a sequence of independent and identically distributed (i.i.d.) random variables with mean zero and variance one, and $\left\{v_{t}\right\}$ is a long-memory process having parameter $d$, with $0<d<0.5$. The fractionally integrated noise model of Hosking (1981) and Granger and Joyeux (1980), i.e., $(1-B)^{d} v_{t}=\eta_{t}$, where $B$ denotes the backward-shift operator $\left(B^{j} x_{t}=x_{t-j}\right)$ and $\eta_{t}$ is a short-memory process, can be used to parametrerize the long-memory process. Typically, $v_{t}$ is assumed to be Gaussian. The conditional variance $\sigma_{t}^{2}$ measures the volatility of $r_{t}$. By taking the logarithm of the squares of the mean corrected returns, $\left\{r_{t}\right\}$, we have

$$
\begin{aligned}
y_{t}= & \log \left(r_{t}^{2}\right)=\left[\log \left(\sigma^{2}\right)+\mathbf{E}\left(\log \psi_{t}^{2}\right)\right]+v_{t} \\
& +\left[\log \left(\psi_{t}^{2}\right)-\mathbf{E}\left(\log \psi_{t}^{2}\right)\right]=\mu+v_{t}+\varepsilon_{t},
\end{aligned}
$$

i.e., $\left\{y_{t}\right\}$ is a Gaussian long-memory signal plus a non-Gaussian white noise. If $\psi_{t}$ is assumed to be Gaussian, $\varepsilon_{t}$ follows a $\log \chi^{2}(1)$ distribution with variance $\pi^{2} / 2$.

Using this formulation, a fully parametric model can be fit to $y_{t}$ by quasi-maximum likelihood estimation (for details, see Section 4 of Breidt et al., 1998). As an illustration of this technique, an estimated LMSV model for the volatility of coffee futures $(\mathrm{KC})$ is presented below. The volatility is modelled as

$$
\log \left(r_{t}^{2}\right)=-0.000086+v_{t}+\varepsilon_{t}
$$

with $\varepsilon_{t}$ independent and identically distributed with mean zero and variance 2.721 , and $v_{t}$ an $\operatorname{ARFIMA}(1, d, 1)$

$$
(1-0.308 B)(1-B)^{0.445}=(1-0.612 B) \eta_{t},
$$

where $\eta_{t}$ is a zero-mean white noise with variance 3.017 .

Note the high estimated value of $d$, relatively close to the stationarity boundary 0.5, implying strong persistence in volatility. As seen in Figure 4 , the autocorrelation structure of the data is matched closely by this model, providing further evidence for the long-memory behavior of the volatility series. 


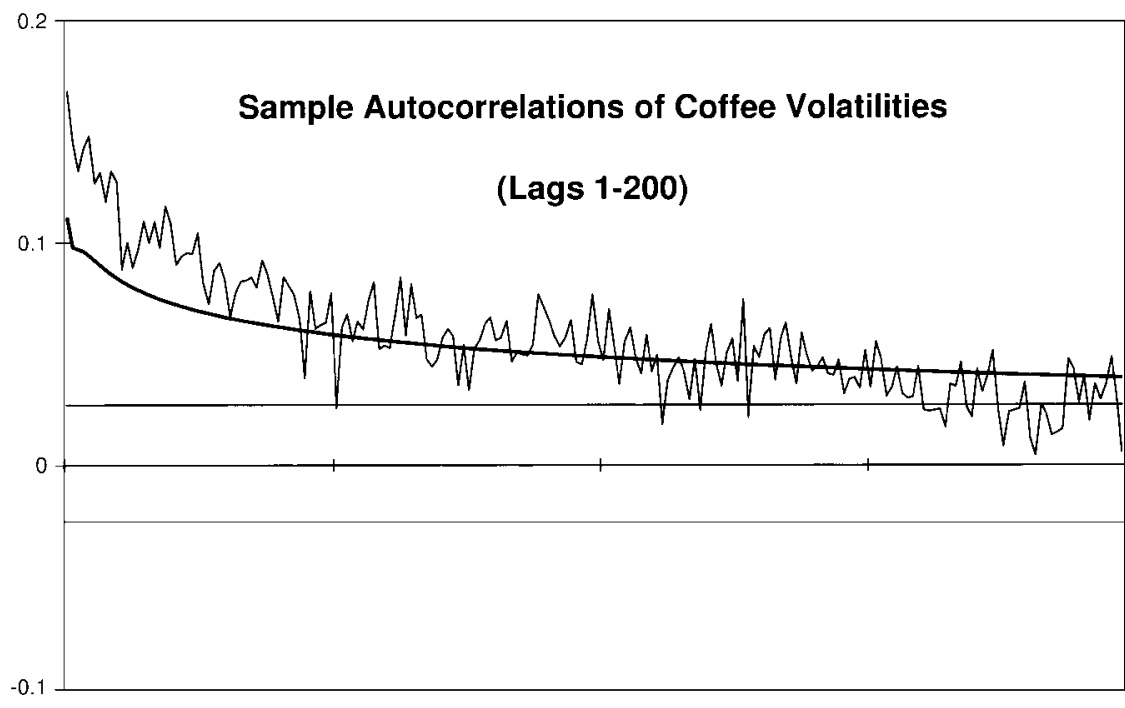

FIGURE 4

The series of futures volatilities display significant positive autocorrelations at high lags with a slow hyperbolic decay characteristic of long-memory processes. Even at lags of order 200, most autocorrelations are significant and positive. The graph shows the theoretical autocorrelation function given by the LMSV model (the smooth line) superimposed on the sample estimates. There is a remarkable consonance between the model and the sample values.

\section{CONCLUSIONS}

This paper reexamines returns on futures' contracts using updated statistical tools. The results provide no evidence of long memory on the series of returns. This contradicts the findings of previous researchers, who have used results from classical $\mathrm{R} / \mathrm{S}$ analysis as evidence to the existence of long memory in futures' returns. On the other hand, the analysis of the volatility of futures' returns indicates a strongly persistent behavior. These are the first findings of this type using futures data. By showing that changes in the variance of financial time series are persistent, i.e., that they remain important for forecasts in large horizons, these results indicate the need for new models for risk assessment of futures' portfolios. In order to evaluate adequately and forecast the risk of a portfolio, analysts should take into consideration the persistent volatility of these financial series.

An additional interesting conclusion deserving for the investigation is the fact that currency futures' volatility seems to have a less-persistent memory than commodity futures' volatility. In the latter case, shocks driving instability in the markets seem to be absorbed faster. 
Appendix

Description of the Extended Data Set

\begin{tabular}{llllll}
\hline Commodity & Symbol & Exchange & Start Date & End Date & Contract Months \\
\hline Soybean Oil & BO & CBOT & $01 / 03 / 77$ & $11 / 28 / 97$ & $1,3,5,7,8,9,10,12$ \\
British Pound & BP & CME & $01 / 03 / 77$ & $11 / 28 / 97$ & $1,3,4,6,7,9,10,12$ \\
Corn & C & CBOT & $01 / 03 / 77$ & $11 / 28 / 97$ & $3,5,7,9,12$ \\
Canadian Dollar & CD & CME & $01 / 03 / 77$ & $11 / 28 / 97$ & $1,3,4,6,7,9,10,12$ \\
Cotton & CT & NYCE & $01 / 03 / 77$ & $11 / 26 / 97$ & $3,5,7,10,12$ \\
Deutsche Mark & DM & CME & $01 / 03 / 77$ & $11 / 28 / 97$ & $1,3,4,6,7,9,10,12$ \\
Feeder Cattle & FC & CME & $01 / 03 / 77$ & $11 / 28 / 97$ & $1,3,4,5,8,9,10,11$ \\
Gold & GC & COMEX & $01 / 03 / 77$ & $11 / 26 / 97$ & $2,4,6,8,10,12$ \\
Copper, High Grade & HG & COMEX & $01 / 03 / 77$ & $11 / 26 / 97$ & ALL \\
Heating Oil & HO & NYMEX & $11 / 15 / 78$ & $11 / 26 / 97$ & ALL \\
Japanese Yen & JY & CME & $01 / 03 / 77$ & $11 / 28 / 97$ & $1,3,4,6,7,9,10,12$ \\
Coffee "C" & KC & CSCE & $01 / 03 / 77$ & $11 / 26 / 97$ & $4,5,7,9,12$ \\
Live Cattle & LC & CME & $01 / 03 / 77$ & $11 / 28 / 97$ & $2,4,6,8,10,12$ \\
Live Hogs & LH & CME & $01 / 03 / 77$ & $11 / 26 / 97$ & $2,4,6,7,8,10,12$ \\
Oats & O & CBOT & $01 / 03 / 77$ & $11 / 28 / 97$ & $3,5,7,9,12$ \\
Pork Bellies, Fresh & PB & CME & $01 / 03 / 77$ & $11 / 28 / 97$ & $1,3,5,7,8,9,11$ \\
Soybean & S & CBOT & $01 / 03 / 77$ & $11 / 28 / 97$ & $1,3,5,7,8,9,11$ \\
Sugar \#11 & SB & CSCE & $01 / 03 / 77$ & $11 / 26 / 97$ & $3,5,7,10$ \\
Swiss Franc & SF & CME & $01 / 03 / 77$ & $11 / 28 / 97$ & $1,3,4,6,7,9,10,12$ \\
Silver & SI & COMEX & $01 / 03 / 77$ & $11 / 26 / 97$ & $3,5,7,9,12$ \\
Soybean Meal & SM & CBOT & $01 / 03 / 77$ & $11 / 28 / 97$ & $1,3,5,7,8,9,10,12$ \\
S \& P 500 Index & SP & CME & $04 / 21 / 82$ & $11 / 28 / 97$ & $3,6,9,12$ \\
\hline
\end{tabular}

CME = Chicago Mercantile Exchange: CBOT = Chicago Board of Trade; COMEX = Commodity Exchange; NYCE = New York Cotton Exchange; NYMEX = New York Mercantile Exchange; CSCE = Coffee, Sugar, and Cocoa Exchange.

\section{BIBLIOGRAPHY}

Andrews, D. W. Q. (1991). Heteroskedasticity and autocorrelation consistent covariance matrix estimation. Econometrica, 59, 817-858.

Baillie, R. T., Bollerslev, T., \& Mikkelsen, H. O. (1996). Fractionally integrated generalized autoregressive conditional heteroskedasticity. Journal of Econometrics, 74, 3-30.

Ball, R. (1989). What do we know about stock market 'efficiency'? In Guimarães, R. M. C., B. Kingsman, \& S. Taylor, (Eds.), A reappraisal of the efficiency of financial markets. Heidelberg: Springer-Verlag.

Barkoulas, J. T., Labys, W. C., \& Onochie, J. I. (1997). Fractional dynamics in international commodity prices. Journal of Futures Markets, 2, 737-745.

Bollerslev, T. (1986). Generalized autoregressive conditional heteroskedasticity. Journal of Econometrics, 31, 307-327.

Bollerslev, T., \& Mikkelsen, H. O. A. (1996). Modeling and pricing long-memory in stock market volatility. Journal of Econometrics, 73, 151-184.

Booth, G., Kaen, F. R., \& Koveos, P. E. (1982a). Persistent dependence in gold prices. The Journal of Financial Research, 5(1), 85-93.

Booth, G., Kaen, F. R., \& Koveos, P. E. (1982b). R/S analysis of foreign exchange rates under two international monetary regimes. Journal of Monetary Economics, 10, 407-415. 
Breidt, F. J., Crato, N., \& de Lima, P. J. F. (1998). The detection and estimation of long memory in stochastic volatility. Journal of Econometrics, 83, 325348.

Cheung, Y.-W., \& Lai, K. S. (1993). Do gold market returns have long memory? The Financial Review, 28, 181-202.

Crato, N. (1994). Some international evidence regarding the stochastic memory of stock returns. Applied Financial Economics, 4(1), 33-39.

de Lima, P., \& Crato, N. (1993). Long-memory in stock returns and volatilities. In Proceedings of the Business and Economic Statistics Section. Alexandria, Virginia: American Statistical Association, 202-207.

Deo, R. S., \& Hurvich, C. M. (1998). On the log periodogram regression estimator of the memory parameter in long memory stochastic volatility models (mimeo). Stern School of Business, New York University.

Ding, Z., Granger, C., \& Engle, R. F. (1993). A long memory property of stock market returns and a new model. Journal of Empirical Finance, 1, 83-106.

Doukas, J. (1990). On unit roots and the persistent dependence of futures prices. Advances in Econometrics, 8, 295-306.

Engle, R. F. (1982). Autoregressive conditional heteroskedasticity with estimates of the variance of United Kingdom inflation. Econometrica, 50, 987-1007.

Fung, H. G., \& Lo, W. C. (1993). Memory in interest rate futures. The Journal of Futures Markets, 13, 865-872.

Geweke, J., \& Porter-Hudak, S. (1983). The estimation and application of long memory time series models. Journal of Time Series Analysis, 4(4), 221-238.

Granger, C. W. J., \& Joyeux, R. (1980). An introduction to long-memory time series models and fractional differencing. Journal of Time Series Analysis, $1,15-29$.

Greene, M. T., \& Fielitz, B. D. (1977). Long-term dependence in common stock returns. Journal of Financial Economics, 4, 339-349.

Harvey, A. C., Ruiz, E., \& Shephard, N. (1994). Multivariate stochastic variance models. Review of Economic Studies, 61, 247-264.

Helms, B. P., Kaen, F. R., \& Rosenman, R. E. (1984). Memory in commodity futures contracts. Journal of Futures Markets, 4(4), 559-567.

Hosking, J. R. M. (1981). Fractional differencing. Biometrika, 68(1), 165-176.

Hurvich, C. M., Deo, R. S., \& Brodsky, J. (1998). The mean squared error of Geweke and Porter-Hudak's estimator of the memory parameter of a long memory time series. Journal of Time Series Analysis, 19, 19-46.

Kennedy, D. (1976). The distribution of the maximum Brownian excursion. Journal of Applied Probability, 13, 371-376.

Lo, A. W. (1991). Long-term memory in stock market prices. Econometrica, 59, 1279-1313.

Lobato, I. N., \& Robinson, P. M. (1998). A nonparametric test for I(0). Review of Economic Studies, 65, 475-495.

Lobato, I. N., \& Savin, N. E. (1998). Real and spurious long memory properties of stock market data. Journal of Business and Economic Statistics, 16, 261267.

Mandelbrot, B. (1965). Une classe de processus stochastiques homothétiques à soi; application à la loi climatologique de H. E. Hurst. Comptes Rendues des Séances de l'Académie des Sciences, Paris, 260, 3274- 3277. 
Mandelbrot, B. (1972). Statistical methodology for nonperiodic cycles: From the covariance to R/S analysis. Annals of Economic and Social Measurement, $1,259-290$.

Mandelbrot, B., \& Taqqu, M. S. (1979). Robust R/S analysis of long-run serial correlation. Proceedings of the 42nd Session of the International Statistical Institute, Manila, Bulletin of the I.S.I., 48(2), 69-104.

Melino, A., \& Turnbull, S. M. (1990). Pricing foreign currency options with stochastic volatility. Journal of Econometrics, 45, 239-265.

Newey, W. K., \& West, K. D. (1987). A simple, positive semi-definite, heteroskedasticity and autocorrelation consistent covariance matrix. Econometrica, 55(3), 703-708.

Robinson, P. M. (1995). Log-periodogram regression of time series with long range dependence. Annals of Statistics, 23, 1048-1072.

Siddiqui, M. (1976). The asymptotic distribution of the range and other functions of partial sums of stationary processes. Water Resources Research, 12, $1271-1276$. 